\title{
An Empirical Study on the Economic Development of Cultural and Creative Industries Park - an Example of Haidian District in Beijing
}

\author{
Hao-lin DI*, Chun-lin TIAN, Ju GUO, Ze-ping HU and Yang YANG
}

Beijing Institute of Economics and Management, Department of Management, Beijing, China

${ }^{*}$ Corresponding author

Keywords: Cultural and creative, Industries park, Economic development.

\begin{abstract}
In this paper, it selects four cultural and creative industry parks in Haidian district as the research objects. The statistical data comes from government department and questionnaire survey including more than 1500 organizations. It calculates the index of the total labor productivity, tax rate, profit margin in the park and so on based on the data of organization's number, income, tax, assets, operating profit and employees. And it expounds the characteristics of the economic development of each park combining with the income distribution structure of 9 industries and characteristic data. Then it probes into the agglomeration capacity of the park, the development stage, the degree of conformity between leading industry and function orientation, and the important problems. At last it puts forward the targeted policy proposal.
\end{abstract}

\section{文化创意产业园区经济发展实证研究一一北京市海淀区为例}

狄浩林 ${ }^{*}$, 田春霖, 郭炬, 胡泽萍, 杨洋

北京经济管理职业学院, 管理学院, 北京, 中国

\section{*通讯作者}

关键词: 文化创意; 产业园区; 经济发展

摘要: 本文选取 4 个海淀区文化创意产业园区为研究对象, 统计数据来源于政府部门和问卷 调查, 涵盖 1500 余家单位。在明确各园区四至范围的基础上, 梳理各园区的面积、功能定位、 核心资源和园区内企业概况等基本信息，利用单位数量、收入、税金、资产、营业利润和从 业人员等数据, 分析了园区的全员劳动生产率、利税率、资产利润率等指标, 结合 9 行业的 收入分布结构和特征数据, 阐述了各园区的经济发展特征, 进而探索园区集聚能力, 发展阶 段, 主导行业与功能定位的吻合程度及主要短板问题, 并提出具有针对性的政策建议。

\section{1. 引言}

文化部“十三五”规划中明确提出文化产业（北京市称为文化创意产业）将发展成为我国 国民经济的支柱产业。文化创意产业园区是文化创意产业发展的策源地和聚集区，具有显著 的引领作用。本文对海淀区辖区内创意设计服务功能区、清华科技园、音乐产业功能区和影 视产业功能区进行了深入的调查, 力图描述各园区的发展情况, 找出园区经济发展特点, 揭 示园区的核心竞争力, 弥补园区发展短板, 推动园区快速发展。

\section{2. 文献综述}

\section{1 文化创意产业及相关概念界定}

1982 年, UNESCO 发表报告: 《文化产业: 文化未来的挑战》，文化产业逐步引起国际 
关注。日本、英国学者先后给出文化产业的定义 (日下公人, 1978; Gamham Nicholas, 1983)。 北京市统计局将其称之为文化创意产业, 指“以创作、创造、创新为根本手段, 以文化内容和 创意成果为核心价值, 以知识产权实现或消费为交易特征, 为社会公众提供文化体验的具有 内在联系的行业集群。”本文认为, 文化创意产业园区是指以创造为根本手段, 从事文化产品 或服务的生产或流通，具有较高附加值的一系列关联企业集聚地。

\section{2 文化创意行业分类}

文化创意产业主要以英国和日本较为典型。英国称之为创意产业, 划分为产品、服务以 及艺术和工艺 3 个大类, 13 个门类。日本创意产业分类标准源于英国, 在此基础上略有修改, 分为服务业和制造业两大类。中国国家统计局将文化产业分为文化产品的生产和文化相关产 品的生产两部分。

北京市制定的《北京市文化创意产业分类标准》(2008) 中分为 3 个层次，第一层次分为 9 个大类, 分别为: 软件、网络及计算机服务; 新闻出版; 广播电视电影; 广告会展; 设计 服务; 文化辅助服务; 文化艺术; 艺术品交易; 旅游休闲娱乐。第二层次分为 27 个中类, 第 三层共有 88 个小类。本文遵循北京市的分类标准。

\section{3 产业园区主要经济理论}

企业间横向或纵向的经济联系表现为产业园区现象。马歇尔的外部经济理论同样适用于 文化创意产业园区。马歇尔将规模经济分为两类, 一类是外部规模经济, 即区域内企业整体 规模经济性; 一类是内部规模经济, 即某企业规模经济性。研究文化创意产业园区经济发展, 不仅要考虑内部规模经济，而且要考虑外部规模经济。

从产业园区实证研究看，基础设施和创新环境是产业园区快速发展的核心，内部的生产 网络和外部的社会网络是产业园区发展动力 (易华等, 2012)。从园区布局来看, 单纯的地理 邻近并不能促成园区内产业合作，而园区布局对技术性企业具有较为明显的推动作用。人力 资源是园区降低创新风险的保证,园区企业和企业家是减少创新风险的核心要素，其增加了创 新的成功率, 缩短了创新时间。产业园区政策方面, 通过对印度班加罗尔的研究, 土地使用、 税收、教育培训、产业和市场政策、科研合作、能源供应、基础设施建设方面对园区发展起 到关键作用。上述研究为海淀区文化创意产业园区提供了基础资料, 为深入研究海淀区文化 创意产业园区的发展动力、成功经验、缺点和短板等具有借鉴作用。

\section{3. 研究范围}

本课题以清华科技园（局部）(以下简称“清华科技园”)、创意设计服务功能区、影视产 业功能区和音乐产业功能区四个园区地理范围内所有的企业作为研究对象。

\section{4. 文化创意产业园区总体经济发展情况}

2015 年, 海淀区文化创意产业园区发展迅猛, 各项优惠政策逐步落实, 为提振产业发展, 凝聚产业动力, 稳定产业规模, 挖掘产业潜力发挥积极作用。通过统计数据采集和问卷调查 补充的方式，上述四个产业园区的经济指标进行统计汇总，结果如下:

表2 2015年四大园区总体情况汇总表

\begin{tabular}{c|c|c|c|c}
\hline 名称 & $\begin{array}{c}\text { 清华科技 } \\
\text { 园 }\end{array}$ & $\begin{array}{c}\text { 创意设计服务功 } \\
\text { 能区 }\end{array}$ & $\begin{array}{c}\text { 影视产业 } \\
\text { 功能区 }\end{array}$ & $\begin{array}{c}\text { 音乐产业 } \\
\text { 功能区 }\end{array}$ \\
\hline 单位数 (家) & 130 & 832 & 302 & 122 \\
\hline 收入 (亿元) & 56.7 & 188.4 & 86.4 & 6.1 \\
\hline 税金 (亿元) & 6.5 & 9.3 & 3.5 & 0.2 \\
\hline 营业利润 (亿元) & 30.5 & 7.1 & 2.3 & 0.2 \\
\hline 资产 (亿元) & 578.5 & 374.3 & 107.4 & 9.2 \\
\hline
\end{tabular}


\begin{tabular}{c|c|c|c|c}
\hline 从业人员 (人) & 6940 & 23763 & 10283 & 1596 \\
\hline 从经济发展情况看, 2015 年, 4 个产业园区中全员劳动生产率 (全员劳动生产率=收入
\end{tabular} 从业人数) 为 79.3 万元。其中, 影视产业功能区全员劳动生产率为 84.1 万元, 位居首位; 其 次是清华科技园, 全员劳动生产率为 81.7 万元, 创意设计服务功能区为 79.3 万元, 音乐产业 功能区为 38.0 万元。全员劳动生产率说明人力资源实现价值的能力, 数值越大, 说明人力资 源实现的价值越大。

2015 年, 4 个产业园区中企业资产利润率为 3.7\%。其中, 清华科技园资产利润率为 $5.3 \%$, 位居首位; 其次是音乐产业功能区, 为 $2.2 \%$, 影视产业功能区为 $2.1 \%$, 创意设计服务功能 区为 $1.9 \%$ 。结合园区企业平均资产情况，企业资产规模与资产利润率有一定相关性。

2015 年，4 个产业园区中企业利税率为 $17.7 \%$ 。其中，清华科技园为 $65.3 \%$ ，位居首位; 其次是创意设计服务功能区, 为 $8.7 \%$, 影视产业功能区为 $6.7 \%$, 音乐产业功能区为 $6.6 \%$ 。说 明企业面临的市场环境优劣，利税率越高，说明市场环境越好，企业盈利能力越强。

综上所述，清华科技园企业规模大，投入多，收益好，呈现出科技型产业园区特征。影 视产业功能区高层次人才集中 (硕士以上从业人员占比达到 $38.6 \%$, 较其他园区高出一倍左 右), 劳动效率高, 企业数量较多, 具有一定的聚集效应, 人才优势较为明显。创意设计服务 功能区企业数量庞大, 经济发展与影视产业功能区没有明显的差异。音乐产业功能区企业规 模小, 效益略差。

\section{5. 各园区经济发展情况分析}

根据 9 大行业分类，统计 2015 年各园区各行业收入情况如下:

表3２015年4个园区9个行业收入情况及占比

\begin{tabular}{|c|c|c|c|c|c|c|c|c|}
\hline 名称 & \multicolumn{2}{|c|}{ 清华科技园 } & \multicolumn{2}{|c|}{ 创意设计服务功能区 } & \multicolumn{2}{|c|}{ 影视产业功能区 } & \multicolumn{2}{|c|}{ 音乐产业功能区 } \\
\hline 项目 & $\begin{array}{l}\text { 收入 } \\
\text { (万元) }\end{array}$ & 占比 $(\%)$ & $\begin{array}{c}\text { 收入 } \\
\text { (万元) }\end{array}$ & 占比 (\%) & $\begin{array}{l}\text { 收入 } \\
\text { (万元) }\end{array}$ & 占比 $(\%)$ & $\begin{array}{c}\text { 收入 } \\
\text { (万元) }\end{array}$ & 占比 (\%) \\
\hline 合计 & 566769.0 & 100.0 & 1883862.3 & 100.0 & 864326.1 & 100.0 & 60580.2 & 100.0 \\
\hline 文化艺术 & 23929.4 & 4.2 & 80566.0 & 4.3 & 8886.0 & 1.0 & 13977.9 & 23.1 \\
\hline 新闻出版 & 20946.6 & 3.7 & 90131.9 & 4.8 & 73774.3 & 8.5 & 3238.1 & 5.3 \\
\hline $\begin{array}{c}\text { 广播、电视、 } \\
\text { 电影 }\end{array}$ & 426.1 & 0.1 & 51931.2 & 2.8 & 152927.0 & 17.7 & 1214.3 & 2.0 \\
\hline $\begin{array}{l}\text { 软件网络及 } \\
\text { 计算机服务 }\end{array}$ & 318886.0 & 56.3 & 634289.5 & 33.7 & 302814.1 & 35.0 & 15813.0 & 26.1 \\
\hline 广告会展 & 1704.5 & 0.3 & 303555.4 & 16.1 & 79620.4 & 9.2 & 9525.6 & 15.7 \\
\hline 艺术品交易 & 0.0 & 0.0 & 657.6 & 0.0 & 467.7 & 0.1 & 809.5 & 1.3 \\
\hline 设计服务 & 22224.9 & 3.9 & 560361.8 & 29.7 & 73306.7 & 8.5 & 4452.4 & 7.3 \\
\hline $\begin{array}{c}\text { 旅游、休闲娱 } \\
\text { 乐 } \\
\end{array}$ & 852.2 & 0.2 & 136583.5 & 7.3 & 48091.6 & 5.6 & 1619.1 & 2.7 \\
\hline $\begin{array}{l}\text { 其他辅助 } \\
\text { 服务 }\end{array}$ & 177799.4 & 31.4 & 25785.5 & 1.4 & 124438.2 & 14.4 & 9930.3 & 16.4 \\
\hline
\end{tabular}

\section{1 清华科技园}

拥有企业 130 家，其中规模以上企业 26 家，规模以下企业 104 家。从行业分类上看，清 华科技园中软件、网络及计算机服务行业的企业最多, 达到 56 家, 占园区企业总数的 $43.1 \%$ 。 行业经济发展结构上看, 2015 年, 清华科技园各行业收入分布 (见表 3), 规模以上软件、网 络及计算机服务行业实现收入 30.1 亿元, 占收入总数的 $53.2 \%$ 。软件网络及计算机服务是清 华科技园的主导行业, 且规模以上企业占主体。作为清华科技园的龙头行业, 软件、网络及 计算机行业中企业平均劳动生产率为 73.9 万元/人; 其中, 规上企业为 103.4 万元/人, 高于海 淀区软件、网络及计算机行业中企业平均劳动生产率 19.3 万元/人，显示出较高的劳动效率。 排在前十位的企业收入达到 43.3 亿元, 占园区企业总收入的 $76.5 \%$; 从业人员达到 4546 人, 
占园区总人数的 $65.5 \%$, 园区核心企业集中度高。

\section{2 创意设计服务功能区}

拥有企业 832 家，其中规模以上企业 104 家，规模以下企业 728 家。从行业分类上看（见 表 3), 创意设计服务功能区中软件网络及计算机服务行业、设计服务行业和广告会展行业的 企业较多, 分别为 356 家、168 家和 116 家, 三类行业企业数量占园区企业总数的 $76.9 \%$; 其 中，三类行业中规模以上企业 83 家，占园区规模以上企业总数的 $79.8 \%$ 。

2015 年，创意设计服务功能区园区企业的平均收入为 2264.3 万元。软件网络及计算机行 业、设计服务行业和广告会展行业中, 企业平均劳动生产率为 80.0 万元/人; 其中, 规模以上 企业为 253.9 万元/人, 显示出较高的劳动效率。园区规模以上企业每平方千米带来的收入为 63.3 亿元，土地资源利用率与园区平均水平基本一致。

\section{3 影视产业功能区}

影视产业功能区拥有企业 302 家。从行业分类上看（见表 3)，影视产业功能区中广播、 电视、电影行业的企业仅为 55 家，占园区企业总数的 $18.2 \%$; 值得注意的是，规模以上广播、 电视、电影行业实现收入 15.3 亿元, 占收入总数的 $17.7 \%$, 高于海淀区该行业收入占比 8.3 个百分点，具有一定的聚集效应。

2015 年, 影视产业功能区园区企业的平均收入为 2862.0 万元。广播、电视、电影行业中 企业平均劳动生产率为 83.6 万元/人; 其中, 规上企业为 102.6 万元/人, 远远低于海淀区广播、 电视、电影行业中企业平均劳动生产率 209.9 万元/人, 说明尽管园区内影视企业集中度较高, 但是劳动效率相对较低, 没有将区内该行业核心企业纳入到影视产业功能区。园区规模以上 企业每平方千米带来的收入为 97.8 亿元，是海淀区规模以上企业同类指标的 7 倍; 其中，广 播、电视、电影行业为 18.6 亿元, 是海淀区广播、电视、电影行业规模以上企业同类指标的 15 倍, 说明重点行业土地利用率较高。

\section{4 音乐产业功能区}

音乐产业功能区拥有企业 122 家。规模以上企业收入仅为规模以下企业的四分之一，说 明园区内企业规模小, 产业凝聚力不足。从行业分类上看 (见表 3), 音乐产业功能区中文化 艺术行业的企业最多, 达到 29 家, 占园区企业总数的 $23.8 \%$ 。2015 年, 音乐产业功能区园区 规模以上企业每平方千米带来的收入为 0.57 亿元, 远低于海淀区规模以上企业同类指标。园 区核心企业集中度低, 排在前十位的企业收入达到 2.2 亿元, 占园区企业总收入的 $36.3 \%$ 。

\section{6. 建议与展望}

\section{1 功能定位准确, 合理制订规划}

调查发现，企业对科技园区的定位还不清楚，甚至有的企业根本不知道科技园区的存在。 同时, 四个园区的差异巨大, 各有特点, 因此建议从功能定位出发, 合理规划园区的发展。“十 三五”期间, 除海淀区文化创意产业的规划外, 还需要对产业园区进行细致的规划, 根据各园 区的现状和发展特点, 进一步延伸文化创意产业规划, 触及园区的功能定位, 助力文化产业 发展。

\section{2 加大扶持力度, 政策精准到位}

建立健全系统性、针对性的政策体系，加大政策落实力度。一是进一步加强清华科技园 创新机制建设, 逐步提升国际范围内的市场整合能力; 二是加快整合创意设计服务功能区企 业资源, 做大做强, 逐步建立企业员工职称评定制度, 吸引高素质人才的加入; 三是积极扶 持影视产业功能区专业化纵深发展，完善产业链，加大对影视历史文化的保护力度; 四是以 音乐核心建筑为中心, 逐步培育音乐市场、引导市场, 建立手工制作、培训、交易市场等完 
整高效的产业环境。

\section{3 加强定期监测, 及时发现问题}

为进一步落实政策规划, 及时掌握园区发展动态, 需要建立长期的监测机制, 以便及早 发现问题, 积极协商解决。根据调查显示, 基础设施好, 政府服务有保障, 有优惠的税收政 策是园区吸引企业的主要原因。而劳动力成本上涨成为企业在生产和采购过程中遇到的主要 问题。企业之所以选择园区办公, 主要是考虑到园区的品牌影响力。建立定期监测制度，不 仅有利于发现问题, 而且有利于量化问题, 预测其发展趋势, 为合理规划资源提供有力保障。

\section{References}

[1] HAI,Jiang TAN Xiang-xun, Differentiating and Analyzing the Concept of Cultural Industry. Academic Exploration. 2005(2):17-20

[2] XIANG Shi-cong, Review of Park Economic Theory[J]. Journal of Jishou University (Social Sciences Edition). 2006(5):97-102

[3] LIN Wen-he, LV Qing-hua, Evolvement and Expectation of Studies on Creative Industries Evaluation Index[J], Commercial Research. 2011(11): 40-43

[4] ZHANG Jun-jun, The Enlightenment of American High-tech Park and the Suggestions of Guangxi Park Economic Development[J], Economic Research Reference. 2011(59): 51-59

[5] YI Hua, YI Xiao-yun, LIU Chang-e, Review of the Research on the Dynamic Mechanism of Development of the Creative Industry Park of World Urban[J]. Economic Exploration. 2012(2): 127-129

[6] ZHANG Ya-ping, ZHANG Xiao, The Revitalization and Enlightenment of Cultural Industry in Japan-Institutional Innovation Perspective[J], Economic Research Guide. 2017(16): 37-38

[7] LIU Yang, GU Hai-bing, Statistics of Cultural and Creative Industries: International Reference and Extension[J], Reform. 2017(6):143-150 